товариство ім. Т. Шевченка у Львові. Т. 8: Париж - Нью-Йорк : Молоде життя, 1976. Репринтне відтворення: Львів, 2000. С. 3155-3157.

9. Український драматичний театр. Нариси історії в 2-х томах. Т. 2. Київ : Видавництво Академії наук Української РСР, 1959. 646 с.

10. Шпаковська Т. Дніпровський академічний музично-драматичний театр імені Т. Г. Шевченка. Київ: Логос Україна, 2018. 245 с.

11. Центральний державний архів-музей літератури i мистецтв України. Путівник. Вип. 1. Київ, 2003. 553 с.

DOI https://doi.org/10.30525/978-9934-26-004-9-51

\title{
АНАТОМІЧНІ РИСУНКИ К. К. КОСТАНДІ 3 ФОНДІВ НАЦІОНАЛЬНОГО ХУДОЖНЬОГО МУЗЕЮ УКРАЇНИ
}

\author{
Мельничук А. I. \\ аспірантка кафедри теорії і історії \\ Національної академії образотворчого мистецттва і архітектури \\ м. Київ, Україна
}

Український художник Киріак Костянтинович Костанді початкову художню освіту здобув у фотографа Булова, а в 70-х роках XIX ст. відвідував класи рисувальної школи Товариства красних мистецтв [3, с. 28]. У 1874 році Костанді вступає до Імператорської академії мистецтв у якості вільного слухача (оскільки не мав атестату про середню освіту). I лише у 1877 році стає студентом Академії мистецтв, де його наставниками були А. Куїнджі, I. Рєпін, І. Крамський, а також П. Чистяков, якого художник згадує з великою повагою та вдячністю. Зі слів сина художника, в академії К.К.Костанді за порадою П. Чистякова, робив багато копій $з$ творів старих майстрів (особливо В. Тіціана та П. Рубенса) в Ермітажі [2, с. 11]. Як зазначав сам Чистяков - «справжня техніка в мистецтві доступна лише художникам, що вивчають анатомію та перспективу, дві необхідні науки, що допомагають піднятись до високого мистецтва».

Принцип наукової обізнаності має важливе значення в академічній системі XIX ст., в час становлення російського реалізму, який дає підвалини до створення методичної бази для художньої освіти. 3 метою підвищення освітнього рівня та художньої майстерності майбутніх митців, 
у період навчання К. Костанді в Імператорській академії мистецтв (1874) для викладання анатомії запросили професора воєнно-медичної академії Ф. Ландцерта. На той час художня академія мала певне методичне забезпечення в кабінеті пластичної анатомії: анатомічні препарати та науково-допоміжні матеріали, такі як схеми, рисунки, методичні посібники, таблиці, моделі тощо. Як зазначає А. Шистер, в період навчання К. Костанді робив навчальні рисунки (рисунок черепа 1878 р. та етюди), що відрізняються м'якістю моделювання світла та тіні [5, с. 12].

В фондах Національного художнього музею України (гр. 2508) знаходиться альбом із 15 анатомічних рисунків художника, зроблених у 1878 році під час навчання в Імператорській Академії мистецтв (про що свідчать печатки від Академії на кожному рисунку).

Рисунки виконані графітним олівцем, а також синім та червоним олівцями. Наприклад, екорше м'язів шиї в профіль та спереду нарисовані графітним та кольоровими олівцями, решта рисунків виконана лише графітним олівцем.

Ці рисунки дають нам змогу проаналізувати вимоги щодо практичних завдань $з$ анатомії у тодішній Імператорській Академії мистецтв, а отже і оцінити рівень художньої підготовки К. Костанді.

В альбомі художника на с. 1, зображений череп в профіль, м'яко промодельовані світло та тінь, можна спостерігати як з правого боку падає освітлення на череп утворюючи тінь за виличним відростком лобової кістки, нижньою щелепою та потиличною кісткою. Рисунок виконаний художньо, в реалістичній манері, також слід зауважити, що художник рисував череп 3 натури. Проте, на с. 8, череп зображений чітко по контуру, що свідчить про його копіювання з посібника по анатомії. Окрім цього, на кожній кістці черепа вказано їх назви. Решта рисунків, виконана $з$ натури - посібників методичного забезпечення кабінету пластичної анатомії. Голова екорше Гудона в профіль та голова екорше в фас виконані не лише графітним олівцем, а й олівцями червоного та синього кольорів, якими автор підкреслив структуру м'язів.

Отже, збережені у фондах НХМУ анатомічні рисунки $3 є$ цінним матеріалом для ознайомлення 3 методичним підходом по пластичній анатомії (1878) в Імператорській академії мистецтв. Як показують анатомічні рисунки виконані К. Костанді в час становлення реалістичної школи в академії, практичне завдання 3 підготовки художників потребувало не лише методичного забезпечення (кістяк, екорше), а й вивчення та засвоєння матеріалу з посібника по анатомії для художників. 


\title{
Література:
}

1. Данилейко В. І. «Щирість, яка струменіє в усьому: в ідеї, кожному штриху, кожному мазку...». До 150-річчя від дня народження одеського художника К. Костанді // Образотворче мистецтво, 2003. № 1.21 с.

2. Киріак Костянтинович Костанді ( художник і людина) [Текст]: спогади про батька сина Михайла Киріаковича Костанді / М. К. Костанді. О.: Астропрінт, 2002. 72 с.

3. Барковська О. М., Єреміна Л. А., Щурова Т.В. Киріак Костанді і художники - греки в Одесі: Кінець XIX - початок XX століть: наукове видання / за ред. В.Ю. Сунцова. О.: Друк, 2002. 204 с.

4. Носенко А. І. Киріак Костанді. Драматургія протиставлень // Образотворче мистецтво, 2009. № $1.10-12$ с.

5. Шистер А. Н. Киріак Костанді. Л.: Художник РСФСР, 1975. 138 с.

DOI https://doi.org/10.30525/978-9934-26-004-9-52

\section{THE IMAGE OF THE CITY IN THE ART OF CHERNIVTSI OF THE 20TH - EARLY 21ST CENTURY}

\author{
Mishchenko I. I. \\ PhD in Art History, Associate Professor, \\ Associate Professor at the Art Examination Department \\ National Academy of Management of Culture and Arts \\ Kyiv, Ukraine
}

The development of the fine arts of Bukovina, particularly active in the 20 th - early 21 st century, is currently insufficiently covered in the research of the scientists. In a few publications, art critics considered mostly the works of individual authors, gave a description of the exhibitions of various exhibitions or projects, and occasionally wrote about the stylistic features of individual works. There is almost no intelligence on the specifics of the existence in the art of the region of different genres and certain topics instead. Exceptions are the editions of 2017: the album «Chernivtsi. Czernowitz» [3] and «Artistic treatises on the city that was once called Czernowitz» [1]. Therefore, it is important to study the principles of depiction of urban landscapes in the paintings and graphics of Chernivtsi artists, the peculiarities of solving their compositions and creations of the city image. 